\title{
Towards a Continuum of Scholarship: The Eventual Collapse of the Distinction Between Grey and non-Grey Literature
}

Marcus A. Banks

New York University School of Medicine Frederick L. Ehrman Medical Library United States of America December 6, 2005 


\section{Agenda}

1. Political history of the open access movement

2. Potential for institutional repositories to increase access to grey literature

3. Eventual collapse of the distinction between grey and non-grey literature 


\section{Political History of the Open Access Movement}

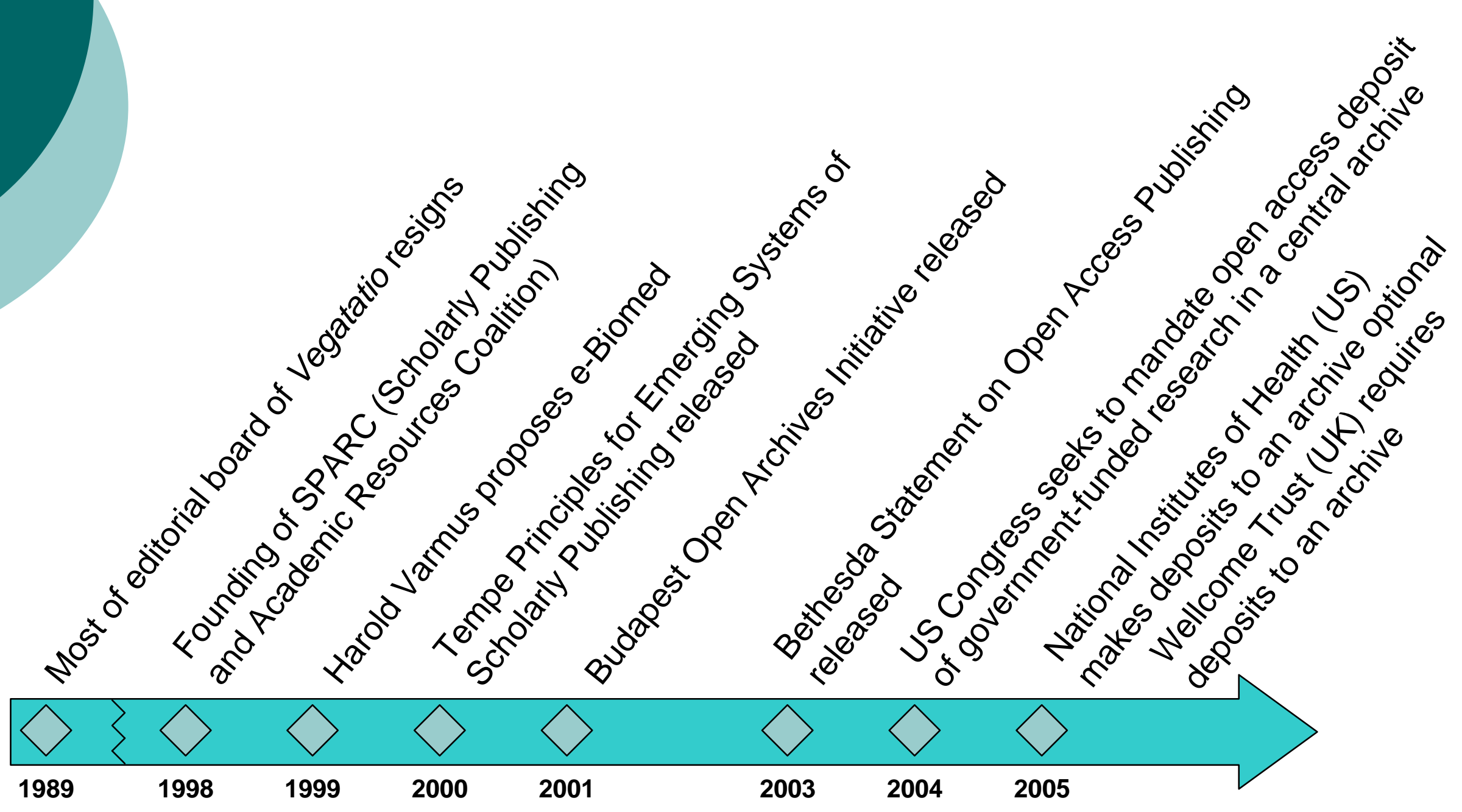




\section{Political History of the Open Access Movement: Alliance for Taxpayer Access}

- Advocates principle that taxpayers deserve full access to government-funded research

o "Peer-reviewed scientific articles" perceived as most critical

- Compelling spokespeople: Patients facing conditions funded by $\mathrm{NIH}$, but who cannot access results of relevant research

o http://www.taxpayeraccess.org/ 


\section{Political History of the Open Access Movement: \\ Lessons for Increasing Access to Grey Literature}

o Key factors in success of open access movement:

- Countries value peer-reviewed scientific articles

- Open access seeks to increase reach of materials that people know they want

- Grey literature advocates should adopt explicit political strategy

- Compelling beneficiary group is critical 


\section{Institutional Repositories: Concept}

- Institutional repositories centralize storage and retrieval of a wide variety of content

- Typically managed by libraries

- Associated with universities, but is applicable to range of institutions

- Open source, freely available repository software

- DSpace Federation:

$$
\text { http://www.dspace.org/ }
$$

o Improvement over self-archiving 


\section{Institutional Repositories: Countries and Contents}

Coverage of Institutional Repositories Related to Type of Objects (In Percentage of Total Objects)

\begin{tabular}{|l|r|r|r|r|r|r|r|}
\hline Countries & Articles & \multicolumn{1}{|c|}{ Theses } & \multicolumn{1}{c|}{ Books } & $\begin{array}{c}\text { Primary } \\
\text { Data }\end{array}$ & $\begin{array}{c}\text { Video, } \\
\text { Music, } \\
\text { etc. }\end{array}$ & $\begin{array}{r}\text { Course } \\
\text { Material }\end{array}$ & Other \\
\hline Australia & 8 & 8 & 1 & 83 & & 0 & \\
\hline Belgium & 33 & \multicolumn{2}{|c|}{66} & & & & \\
\hline France & 80 & 20 & & & & \\
\hline Germany & 20 & $40-50$ & & 5 & 1 & 25 \\
\hline Italy & 70 & \multicolumn{2}{|c|}{5} & & & 20 & 5 \\
\hline Norway & 10 & 90 & & & & \\
\hline Sweden & 30 & 70 & & & & \\
\hline The Netherlands & 20 & 40 & & & & 40 \\
\hline United Kingdom & 74 & 16 & 1 & 4 & & 4 \\
\hline
\end{tabular}

Source: Academic Institutional Repositories: Deployment Status in

13 Nations as of Mid 2005 (D-Lib Magazine, September 2005) 


\section{Institutional Repositories: Challenges}

- Difficult to convince researchers of benefits of institutional repositories

- Consequent lack of interest in depositing materials, even if they will be managed by others

- Will take further evaluation to determine if institutional repositories reach full potential

- For now, coverage of grey literature in institutional repositories is encouraging 


\section{Collapse of Distinction Between Grey and non-Grey}

Literature

- Primacy of peer-review articles an artifact of print-based system

- Valuable, but not an inherently superior way to depict research results

- Now that institutional repositories have eased distribution, grey literature is more accessible than ever before

- A hierarchy between peer-reviewed and grey literature apparent in institutional repositories, but it is softer than in traditional scholarship 


\section{Collapse of Distinction Between Grey and non-Grey Literature (Cont.)}

$\circ$ Envisioning the Future:

- Continuum of scholarship rather than a hierarchy

- Grey literature just as valued as peerreviewed materials

- Peer-review ratifies rather than validates scholarship

- Core of scholarship is contained in the grey literature 


\section{Selected Resources}

- Timeline of Open Access Movement: http://www. earlham. edu/ peters/fos/timeline.htm

- Institutional Repositories: Essential Infrastructure for Scholarship in the Digital Age": http://www.arl.org/newsltr/226/ir.html

- "Understanding Faculty to Improve Content Recruitment for I nstitutional Repositories": http://www.dlib.org/dlib/january05/foster/01foste r.html

- "Academic Institutional Repositories: Deployment Status in 13 Nations as of Mid 2005": http://www.dlib.org/dlib/september05/westrienen/ 09westrienen.html 


\section{Creative Commons License}

- This work is licensed under the Creative Commons AttributionNonCommercial 2.5 License. Anyone may re-use it with proper attribution, for non-commercial uses. Please visit http://creativecommons. org/license s/by-nc/2.5/ for further information. 